\title{
WHO Fever Management Guidelines: Challenges in Harnessing the Benefits
}

\section{During Covid-19 Pandemic}

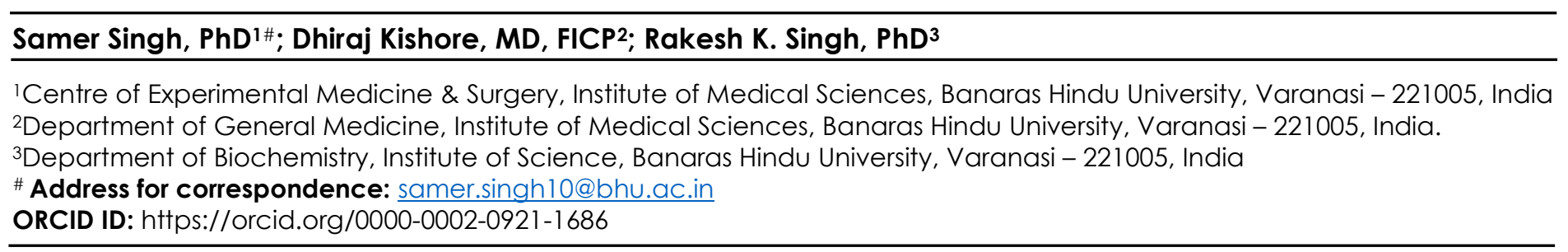

\section{ABSTRACT:}

Fever remains an integral part of the acute clinical diseases management, esp. viral, for which effective therapeutics remains desired. However, the presence of often confusing fever reduction recommendations for COVID-19 in the public domain during the pandemic, as late as 28 April 2021, seems to suggest the reduction of any 'uncomfortable' fever ranging from 37.8 - $39{ }^{\circ} \mathrm{C}$, as opposed to WHO fever reduction guidelines $\left(\geq 39^{\circ} \mathrm{C}\right)$, urgently need attention. The confusion could percolate down into different agencies who look up to these agencies for guidance in framing their own, denying the benefits of fever to populations, and effectively undo whatever successive WHO's guidelines have achieved in the last two decades. The existence of conflicting guidelines in public domains which are open to interpretations has consequences to public health and the healthcare infrastructure, on implementation. For controlling acute infectious diseases, esp. viral, the fever remains the most important enabler. Historically, our chief obstacles to harnessing the benefits of fever in acute clinical diseases with limited therapeutics had been: a) widespread myths about 'fevers' arising from a general misunderstanding of basic facts; b) presence of confusing guidelines by different agencies which are open to alternate interpretation. The article attempts to briefly indicate the benefits of fever in disease resolution, dispel myths, underline vagueness in illustrative national guidelines and the need to align them with evidence-based WHO guidelines, as it has the potential to perpetuate myths/confusion in masses leading to adverse impact on disease management - more morbidity and mortality from diseases including COVID-19.

Key Words: Beneficial Fever, Infections, WHO, Fever Management, Myths, Guidelines, Antipyresis, Mortality, Heat Shock, Inflammation, Respiratory diseases, ARDS, COVID-19, Paracetamol

\section{INTRODUCTION:}

Fever is an essential part of our natural defense mechanism against acute clinical infections, esp. for whom effective therapeutic agents are limited, e.g., common cold, measles, influenza, etc. [1-8]. The existence of fever is an evolutionary conserved adaptive response, at least $>400$ million years old, not just unique to us that protect hosts from potentially dangerous pathogens causing improved survival and early resolution of infections, while reduction of fever in diseases is associated with increased mortality including those in critical conditions [REFs in 1,2,5,6,9-11]. The role of fever in controlling infectious disease is well recognized and remains part of standard immunology textbooks, clearly enumerating its benefits. For example, Janeway's Immunobiology states "At higher temperatures, bacterial and viral replication is less efficient, whereas the adaptive immune response operates more efficiently" [12, p. 110]. Kuby Immunology [13] variously describes the benefit of 'fever' as "helps to eliminate many temperaturesensitive bacterial strains" [p.223], "a protective response, as elevated body temperature inhibits replication of some pathogens' [p.323], 'decrease microbial viability" [p. 401]. However, its true value remains highly underappreciated in the age of antimicrobials where most of the fatal diseases have been largely controlled using vaccines. There had been a sea change in the practice of antipyretics in the last $50-60$ years [14-22]. Now, antipyresis seems to be recommended for every fever no matter how insignificant it may be in the case of infectious diseases, even as low as $37.8^{\circ} \mathrm{C}-38^{\circ} \mathrm{C}$, unqualified 'uncomfortable feelings' or 'feeling uncomfortable' [23-24]. Recent publications of information and guidelines for COVID-19 [25-28] in disagreement with the World Health Organization (WHO)'s fever reduction guidelines as well as various national/ local guidelines for fever management are a cause of concern [29-33]. These conflicting guidelines would have the potential to promote unnecessary fever reduction which could increase the deaths 
from unrelated acute clinical diseases for which we may also not have therapeutic agents yet.

The aversion to high temperature or the notion of 'fever is obnoxious' is not very old. Fever has remained an evolutionary conserved important ally in our fight against diseases and its value has remained well recognized in certain diseases and conditions since the time of Hippocrates [34-36]. Extending on to what was indicated in the literature, the well-documented display of fever's value in disease resolution by Julius Wagner-Jauregg in the early part of the $20^{\text {th }}$ century helped firmly establish and popularize the benefits of fever in treating otherwise untreatable infectious diseases [37]. Its contribution to propel the growth in our understanding of the molecular basis of fever and its role in pathogen clearance is exemplary. Wagner's work firmly established the role of fever in disease by showing that induction of fever in neurosyphilis by the introduction of the malaria parasite was curative, which effectively changed an essentially non-treatable condition characterized by progressive paralysis, to a treatable one. For his monumental work on establishing the therapeutic value of fever in disease, he was awarded the Nobel prize in the year 1927. Since then, extensive work of many scientists has contributed to the overall understanding of the essential indispensable beneficial role of fever in disease control [REFs in 113]. However, the discovery and increasing availability of antibiotics combined with most dreaded diseases controlled by vaccination programs in the latter part of the last century made reliance on fever for the resolution of common pathogen-caused diseases largely redundant for physicians, besides slowly erasing its benefits from the public memory. The manuscript attempts to briefly indicate the role of fever in disease resolution, dispel fever paranoia, why it is important to appropriately manage fever as suggested by WHO's fever management guidelines esp. for viral diseases, possible health and implementation issues arising from inexact confusing descriptions in different COVID-19 guidelines in public space by various agencies and the possible way forward.

\section{WHAT FEVER DOES?}

The benefits of fever in controlling infection are many and are beyond the scope of current discussion [REFs 1-22]. During infection brain elevates body temperature in increments effectively increasing its thermotolerance for the next possible higher temperature exposure, after each cycle figuratively speaking, assessing the benefits-driven and preparing for the next round of onslaught on pathogen through a further increase in temperature as needed. The anti-inflammatory benefits from high fever $\left(>39-42^{\circ} \mathrm{C}\right)$ remain some lesser-known facts. Permanent ill effects have not been recorded for fevers from the normal course of infections up to $42^{\circ} \mathrm{C}[20]$. One of the reasons for prevailing WHO's guidelines recommendation of suggesting a delay of antipyresis $\geq 39{ }^{\circ} \mathrm{C}$ is the fact that raising of the body temperature to about $39 \circ \mathrm{C}$ has been known to inhibit the replication of most of the viruses and bacteria (restrictive temperature) infecting humans [38] and the reported beneficial decrease in the minimum inhibitory concentration of antimicrobials for tested pathogens by $4-16$ times by $41.5^{\circ} \mathrm{C}$ as compared to that at $35^{\circ} \mathrm{C}$ [39]. For pathogens with higher restrictive temperature the benefit of raising the fever remains grossly underappreciated, e.g., at $41-42^{\circ} \mathrm{C}$ the replication of poliovirus is reduced by 200 fold [40] while the serum-induced lysis of Gramnegative bacteria is greatly enhanced [41]. It also triggers the accumulation of various Heat shock proteins (HSPs) and metallothioneins within hrs as a part of heat shock response (HSR) to prepare and protect the cells from future higher temperatures exposures (next day) and possible inflammation damage if the situation is warranted [REFs in 42-46]. Temperature elevation (about $40^{\circ} \mathrm{C}$ ) is known to enhance the production of interferons (IFNs) by infected cells that help the surrounding uninfected cells attain viral infection refractory state through induction of a complex web of host genes leading to inhibition of viral infection and replication, and various interleukins that help enhance bacterial clearance and help reduce inflammatory damage [REFs in 1, 46-49]. The IFNs enhance cells' capacity to inhibit and eliminate viral infection by enhancing innate and intrinsic antiviral responses [50]. This enhancement could be part of a failsafe mechanism for those pathogens or viruses who have escaped lower temperature exposures (mutants) or whose replication could not be inhibited at a lower temperature due to the temperature being permissive for them [REFs, 38-40,51]. The feverinduced HSR further prepares cells to amicably resolve any threatening stressful situations of thermal, oxidative, and metabolic nature that may arise later from an overwhelming inflammatory response to persisting infection [REFs 52-54]. The HSR is known to be enhanced by repeated heat shocks (including recurrent fever), estrogens (E2) as well as cyclopentenone prostaglandins produced in later stages of disease/inflammation. The appearance of fever with an increasing magnitude over time also prepares host cells through HSR to be able to withstand 'supraphysiological temperatures' that the host may be exposed to contain the infection in the future which would otherwise be deleterious.

The HSR and IFNs, together, orchestra a balanced inflammatory response that minimizes host damage 
without jeopardizing an aggressive cell-mediated response, e.g., activation of cytotoxic activity of NK cells, K- cells, T-cells, activation of Macrophages cytocidal activity, activation of suppressor T cells, etc, that may be desired to eliminate the pathogen [REFs in $1,12,13,44,46$ ]. It may be of general interest that the generation of robust HSR is also suppressed to various degrees in most of the COVID-19 pertinent comorbid conditions characterized by chronic inflammation (cardiovascular, obesity, frailty, obesity, diabetes, including metabolic syndrome conditions [55].

\section{PERVASIVE 'FEVER' PARANOIA: PREVALENCE, CAUSE, AND POSSIBLE SOLUTION}

Despite obvious established benefits of fever in infectious diseases, the harnessing of its benefits in need remains desirable due to lack of knowledge and education, essentially perpetuating the nonevidence-based management practices [14-22, 5658]. The unawareness among the masses, nursing staff, and clinicians of the vital beneficial role of fever in infections remain extensive, despite the body of theoretical and practical/experimental evidence to the contrary [14-22,36,56-58]. The decrease in the awareness about fever's beneficial role in infections and the concomitant urge to treat all fevers has been gradual, peaking in the last three decades. Various estimates put rapid increase during 1980s to 2010 among clinicians (12\% to $65 \%$ ) $[3,20]$, nursing staff $(70 \%)[59,60]$ and parents $(60 \%$ to 90-95\%) in countries like USA [REFs in 3,20-22, 59-17]. The situation in other countries may not be drastically different $[19,21,22,36]$. The WHO and various national agencies/bodies have been making efforts to educate and improve the practice through publications from time to time [29-33], stressing the beneficial role of fever in infections and restricting antipyretics usage to temperatures $\geq 39{ }^{\circ} \mathrm{C}$ when defined uncomfortable conditions are present (See section 'Fever Management Guidelines'). The rational use of antipyresis may have further gone down during COVID-19 with the publication of confusing and contradicting guidelines by different national agencies (e.g., National Health Service (NHS), Scotland, National Institutes of Health (NIH), USA and Indian Council of Medical Research (ICMR), India) which are in conflict with existing WHO guidelines and seem to suggest anything to everything from $37.8^{\circ} \mathrm{C}$ to $39^{\circ} \mathrm{C}$ fit for antipyretics treatment [23-28]. Few illustrative examples from different national agencies which may be contributing to the prevailing confusion and hence increased inappropriate usage of antipyretics during the COVID-19 pandemic are discussed later. An increase in unnecessary antipyretics usage could have an upsetting impact on the health of individuals and the health infrastructure. The possibility of the health of masses getting adversely impacted from needless antipyretics usage cannot be ignored given its precedence $[3,5,6,10,11,49]$.

The current notion of treating each and every uncomfortable 'fever' despite efforts to educate the masses by agencies like WHO is seemingly contributed by some underlying facts and possible solutions briefly discussed below.

Firstly, inability to differentiate fever by type, i.e., 'Hyperpyrexia', the brain-controlled incremental increase in temperature observed over a period during infection, from 'Hyperthermia', the uncontrolled temperature elevation as from heat shock or failure of the thermoregulatory mechanism. The blame also partly lies in the oversight of preferential use of generalized term 'fever' and 'Hyperthermia' in literature for any temperature elevation above $37{ }^{\circ} \mathrm{C}$, where the use of the term 'Hyperpyrexia' or some more widely agreed precise terminology (e.g., 'pathogen-hyperpyrexia') would have been more accurate for the uninitiated. Equal blame could be placed on its liberal use to a range of temperatures, making the situation chaotic where any elevation of the body temperature could be construed as 'hyperthermia' so naturally 'dangerous' and 'fit for treatment' in the eyes of the general population. In literature, the term 'hyperpyrexia' has been also used for anesthesiadriven uncontrolled temperature elevation [61]. It should be clarified that while for uncontrolled hyperthermia the temperatures around $40^{\circ} \mathrm{C}$ or higher could be lethal, the case for controlledhyperthermia or more appropriately the 'hyperpyrexia' (or infection driven hyperpyrexia or 'pathogen-hyperpyrexia') temperature up to $42^{\circ} \mathrm{C}$ (108 F) are considered within safety limits (See Table 1 ; 58). There is an urgent need to clarify the terminology in the literature and arrive at a consensus to remove the currently chaotic perception among a large majority of clinicians and the normal populace alike. Additionally, in clinical practice, many a time it is difficult for physicians and healthcare staff to know the origin of fever, so the alleviation of symptoms takes precedence. Naturally, it makes the scenario conducive for clinicians and individuals to act upon the logical 'well-intentioned' step of 'why take chances' when antimicrobials and antipyretics are readily available $[62,63]$. However, the prescription of antipyretics for diseases without antibiotics or antivirals available for use makes it a risky proposition. 


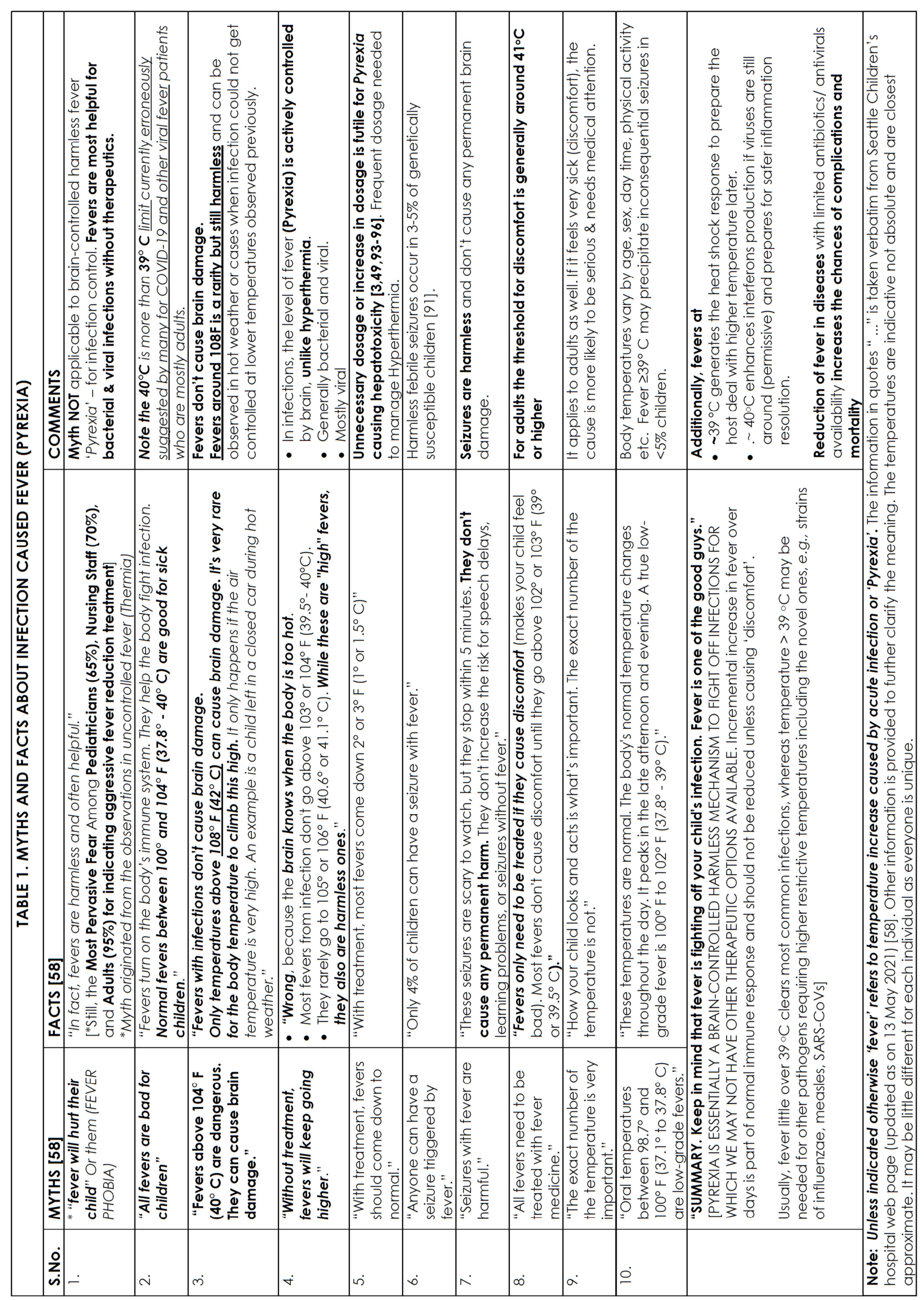


Secondly, fear of brain damage from high fever. The assumption is valid for hyperthermia but invalid for hyperpyrexia. The widely ingrained fear of brain damage in populations including the physicians perceptibly originates from the experience of seizures and writhing observed in $2-5 \%$ children $<5$ years of age around $39{ }^{\circ} \mathrm{C}$ of pyrexia, largely ignoring the hard evidence that no one died or had brain damage as a result of normal course of pyrexia in almost last one century except an oftenquoted anecdotal report from the 1950s [64]. One study estimated that up to $65 \%$ of physicians indicated that fever was harmful and $90 \%$ believed that febrile convulsions could cause brain damage $[18,20]$.

Thirdly, in the clinical practice of a physician that currently largely relies on antibiotics, there appears to be "no evidence of ill effects" of fever reduction. Since the 1950s, progressively, most acute diseases got controlled by vaccines, availability and heavy reliance on the use of antibiotics/antivirals has made the dependence on fever for the resolution of common diseases largely redundant.

Fourthly, most of the dangerous pathogens with the potential to cause heavy mortality affecting humans to have a restrictive temperature around $39^{\circ} \mathrm{C}$, so antipyresis $\geq 39 \circ \mathrm{C}$ had been mostly inconsequential in clinical practice possibly leading to progressive abandonment and loss from public memory. However, when caring for a disease whose causative pathogen has a restrictive temperature above $39^{\circ} \mathrm{C}$, the effect of unnecessarily keeping the temperature down would range from inconsequential to disastrous to patients depending upon their genetic makeup, the virulence of the pathogen, prevailing protective immunity/ previous exposure, health status, age, comorbidities (see the section below), etc.

Fifthly, many a times physicians tend to make the oversight of equating 'no evidence of harm' with 'evidence of no harm', in prescriptions though largely understandable in their practice and scope, these are fatal flaws in epidemic situations or when dealing with a new disease where nature of the pathogen is unknown and the therapeutic options available are of limited use. Under these circumstances, unnecessary fever reduction could help wider dissemination of unrelated pathogens/diseases as modeled for influenza [65] besides the obvious potential to increase the severity and mortality from pathogens for which suitable therapeutic agents (antibiotics, antivirals) are unavailable.

Sixthly, the underappreciation of the role of fever in disease resolution and perpetuation of myths among medical students and future practitioners are partially contributed by widely used medical textbooks' unqualified remarks without clarifying the context to students, e.g., Harrison's Principles of Internal Medicine, [66, p.104] under "The Decision To Treat Fever" states "treatment of fever and its symptoms does no harm and does not slow the resolution of common viral and bacterial infections". Many health care providers seem to err to equate 'common' with 'all' infections in their practice where effective therapeutics are "commonly" available. They also fail to miss the immediate context in which text would be applicable, i.e., "Most fevers are associated with self-limited infections, such as common viral diseases". Generalization of something applicable to 'common' and 'self-limiting diseases' to 'all diseases and conditions would have no consequences for 'common diseases' but their non-applicability to the treatment of those rare or novel diseases which do not have effective therapeutics available or the therapeutics is not being co-administered with antipyretics need to be always remembered or highlighted by the internal medicine textbooks as the fever has an unquestionable essential role in the resolution of diseases of undetermined origin for which therapeutics are limited [8].

\section{WHY THE FEVER REDUCTION MAY BE MORE PROBLEMATIC TO SOME THAN OTHERS?}

Suppression of initial low-grade fever that prepares host to minimize damage from a future surge of cytokines besides keeping the infection down, would logically increase the risk of being exposed to sudden overwhelming cytokine storm and experience adverse complications due to host bodies' non-preparedness, i.e., reduced capacity to resolve the ensuing damaging inflammation [4-6, 12 , 13]. The induced normothermia by antipyretics or non-steroidal anti-inflammatory drugs (NSAID) has the capacity to blunt the HSR and essentially the capacity of the host to suitably respond to resolve inflammation triggered in the future to clear an infection. Fever-induced HSR response through HSFl also controls the expression of proinflammatory cytokines including IL-6 which had been purported to be one of the culprits behind cytokine storm and increased mortality in diseases precipitating acute respiratory distress syndromes [1, 52, 53, 67-69].

The intact HSR circuitry along with HSF-1 that may be variously deficient in different backgrounds is required for generating appropriate cytokine responses, protection from inflammation [52-54] as well as IgG response [70]. It would be noteworthy that most conditions currently identified to be associated with higher mortality including COVID-19 as well as other respiratory tract viral infections are 
also characterized by increased prevalence of reduced and/or defective HSR, e.g., aging [71], diabetes (both types 1 and 2) [72-73], acute respiratory distress syndrome [74], sepsis [75-76], renal failure [77], cigarette smoking [78], and chronic obstructive lung disease [79].

The induced normothermia by antipyretics usage has been shown to increase viral shedding and prolonging recovery [80-81] while associated with increased mortality from pneumonia [82-85] and reduced activity of antibiotics towards all tested pathogens to date $[38,39]$. The individuals unable to generate appropriate HSR would be logically more prone to adverse outcomes from unnecessary antipyresis during infections. Metanalysis of animal studies using animal models of influenza has indicated an increased pooled odds ratio of 1.34 for mortality with the antipyretics use [86]. Interestingly, hyperthermia preconditioning had been demonstrated to decrease mortality in models of various relevant conditions like sepsis [87], stroke [88], myocardial infarction [89], and hepatic ischemia [90]. It may be pertinent here to remind that before the discovery of antibiotics and their availability became widespread, the fever had remained a known beneficial ally for infectious disease resolution.

\section{FEVER MANAGEMENT GUIDELINES}

The current WHO guidelines for fever management explicitly stipulate that febrile illness from infections with a fever of $>39^{\circ} \mathrm{C}$ and presented with defined acute complications or discomfort could be considered for fever reduction [29]. Furthermore, treatment should focus on the cause of fever rather than the fever itself which is known to have a beneficial role in infection resolution. Refer to Table $2 a$ for an excerpt from guideline (Chapter 10: Management of Fever; p305) that restricts antipyresis to 'children uncomfortable or distressed because of fever' and mentions it may not benefit otherwise active and alert children besides compromising the immune defense, for general reflection. Furthermore, it should be noted that fever reduction for children is not part of 'treatment' but only part of 'Supportive Care' that too under 'conditions' explicitly causing distress and discomfort ('If the child has a high fever $\left(\geq 39^{\circ} \mathrm{C}\right.$ or $\geq 102.2^{\circ} \mathrm{F}$ ) that is causing distress or discomfort') [29]. It attempts to explicitly underline the fact in uncertain terms that antipyretics do not provide benefit to infectious disease resolution but may be needed for other conditions including hyperthermia. It should be

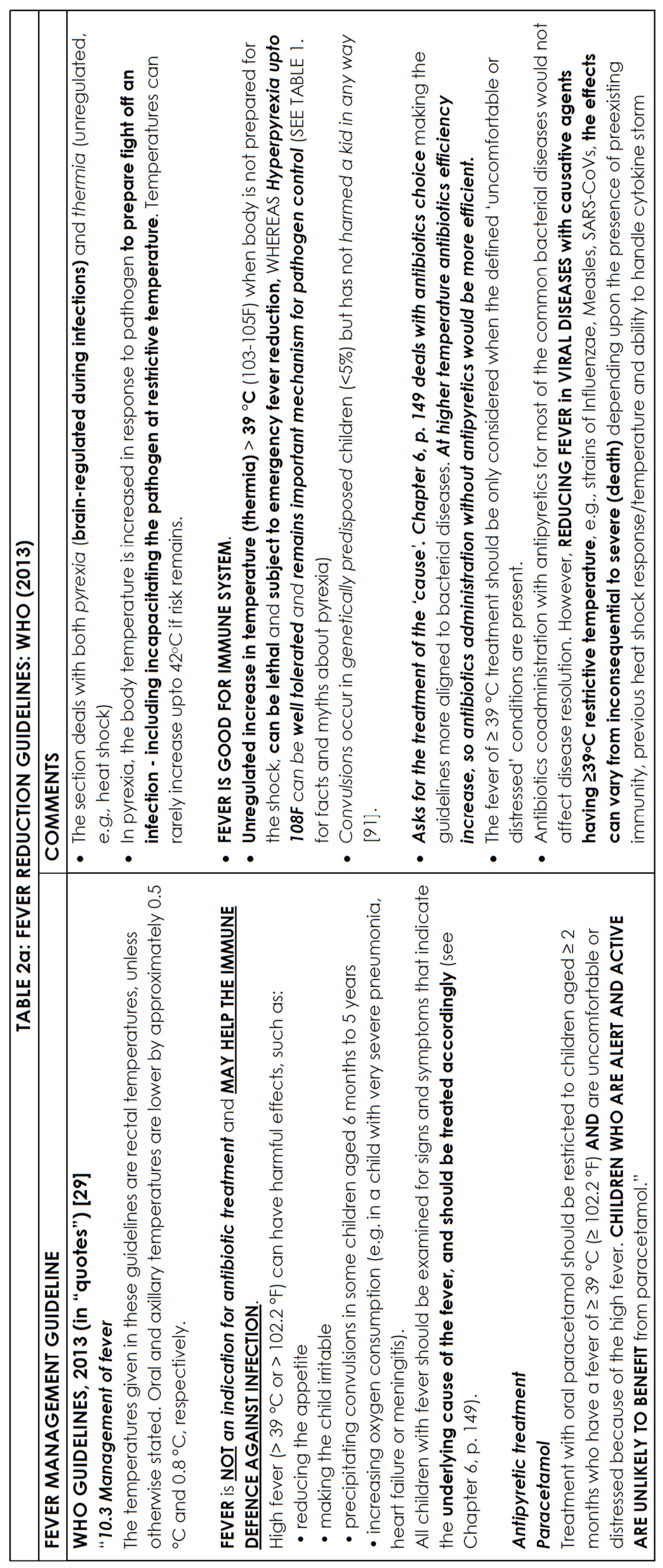


remembered that the guidelines of fever management are for 'the most vulnerable', i.e., $~ 5 \%$ of children $<5$ years of age that are presented with complications and discomfort like neck stiffness, genetically predisposed seizures/convulsions [91], etc. The consideration of fever reduction should weigh the potential benefit being derived, as the most commonly observed seizures/convulsions though scary to watch are inconsequential to children's wellbeing $[29,49,58,91]$.

It may also be time to clearly identify the temperature range that is harmless in infections. Upwards revision of the temperature range for fever reduction consideration may also be undertaken. Soon after the publication of the first guideline by WHO in 2000 [92], a metanalysis published in the bulletin of WHO [58] under section 'Policy and Practice' identified $41^{\circ} \mathrm{C}$ as "normal febrile range", highlighted the continued practice of antipyresis as "parents and health professionals routinely treat fever in young children" despite the clear cut realizations of "fever helps survival during infection, and that antipyresis increases mortality" in many diseases and the "potential for hepatotoxicity" and "overdosage" [93-96]. It goes on to indicate "WHO recommendations for the management of fever in children include the use of paracetamol for children with fever of $\geq 39{ }^{\circ} \mathrm{C}$ " despite "Insufficient data, however, support this recommendation" and suggests "We recommend that health professionals should not be encouraged to give antipyretics routinely to febrile children. Treatment should only be given to those children in obvious discomfort or those with known painful conditions" [58]. Understandably, these recommendations with revised fever reduction guidelines and discourse were included in the revised guidelines for fever reduction by WHO in 2013 [29] (See Table 2a). However, the paranoia of bad fever still continues.

The thoroughly revised second edition of fever reduction guidelines from WHO published in 2013 [29] has been an excellent comprehensive endeavor to increase the understanding among healthcare providers and parents alike for adherence to appropriate usage and hence maximize the benefits. Despite the clear benefits of fever in infection resolution, WHO's endeavors to spread awareness, which has become more important during the ongoing COVID-19 pandemic due to potential for abuse and its implication to different diseases including the COVID-19 itself, the confusion seems to be not abating. (See Table $2 b$ for illustrations about the current guidelines from different national agencies around the world)

\section{WHAT MORE COULD BE DONE?}

The existing guidelines for fever management in the public domain including those for COVID-19 [23-28] could be made more clarifying and explicit in stating the dangers of unnecessary fever reduction and underline the essentiality of fever in resolving diseases caused by pathogens for which antimicrobials are of little use. Additionally, the guidelines could consider including explanatory myth dispelling statements suitable for masses as shown by Seattle Children's Hospital to allay the fear of hyperpyrexia and establish its positive benefits [58]. Previous publications of the guidelines meant to be manual for trained skilled healthcare personnel needs to be aligned with the understanding of the masses that now have greater access to these documents, so explicitness needs to be the cornerstone of these guidelines to drive the benefits without endangering the lives. The guidelines should consider explicitly identifying the small minority of people to seek immediate medical attention who are at a higher risk of complications from temperatures $\geq 39^{\circ} \mathrm{C}$, e.g., pregnant women (3-4 weeks), frail who may not even attain $39^{\circ} \mathrm{C}$, children $<5$ years, individuals unable to generate HSR response, etc. (see sections above). In the age of increased access to information, these clarifications or explicitness in the guidelines is more of necessity than desire before placing them for public access by agencies to which people now actively look during the crises. In the current pandemic situation, inappropriate antipyresis could be contributing to the unspecified number of increased complications and mortality from different infectious diseases including the common seasonal viral diseases. Making guidelines immune to misinterpretation will have the potential to remove the fear of fever (pyrexia) from the masses and decrease the chances of complications and deaths in the vulnerable populations arising from inappropriate usage of fever-reducing agents.

Fever is an essential part of the acute-phase response that besides providing stimulus to the immune system and prepare for ensuing inflammatory response, helps contain the pathogen growth and promotes clearance through increased chemotaxis, phagocytosis, and reactive oxygen radical formation. It gains prominence for the resolution of diseases caused by pathogens with limited therapeutic options. The WHO Guidelines, 2013 had been explicit in identifying the benefits of fever and indicate when fever should be treated. During COVID-19, the presence of various guidelines in the public domain that are seemingly in conflict with WHO guidelines, as well as those of various national agencies may be unknowingly promoting the unnecessary antipyresis endangering public health. It may be in the general benefit of people at large that these conflicting guidelines must be 


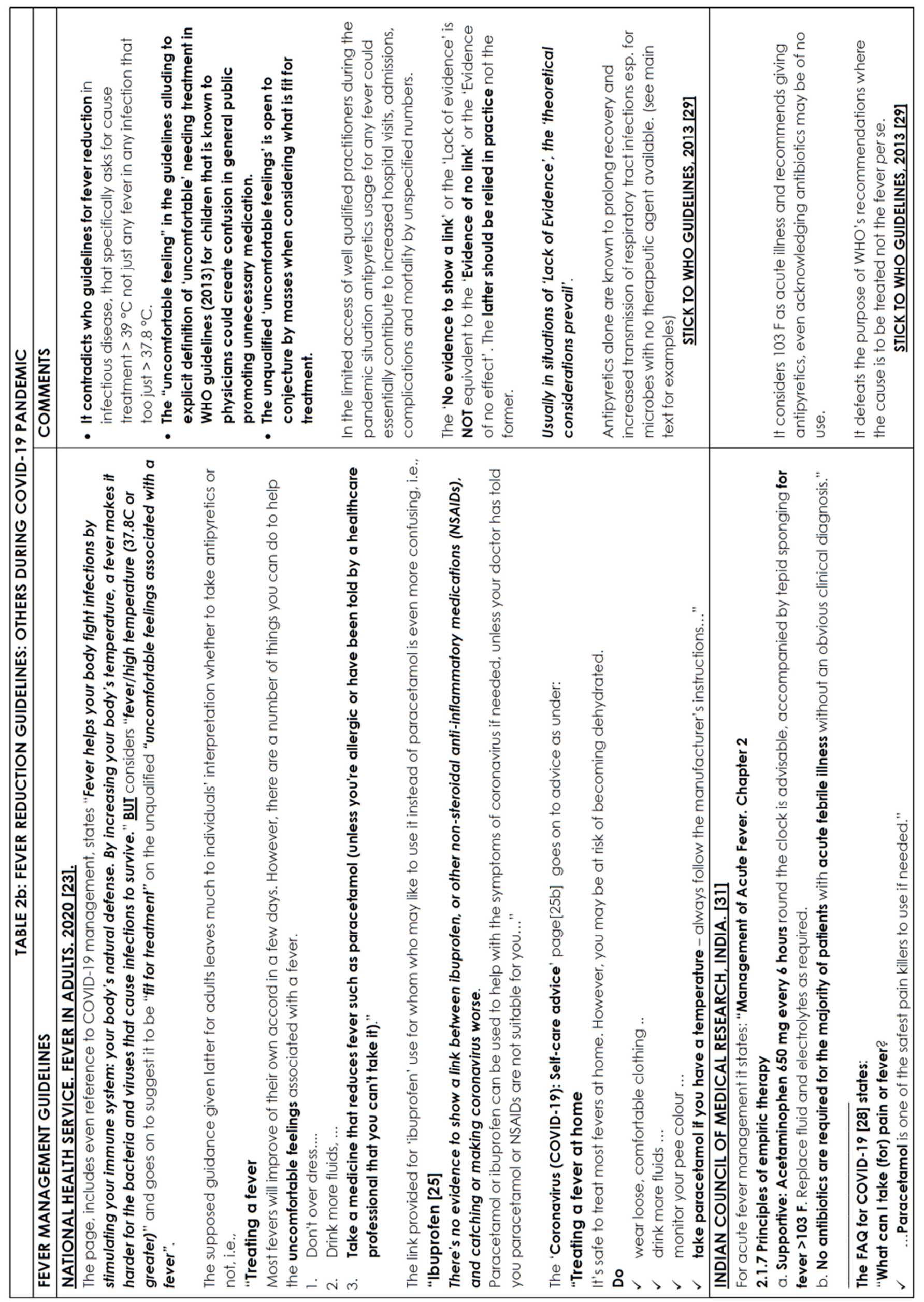




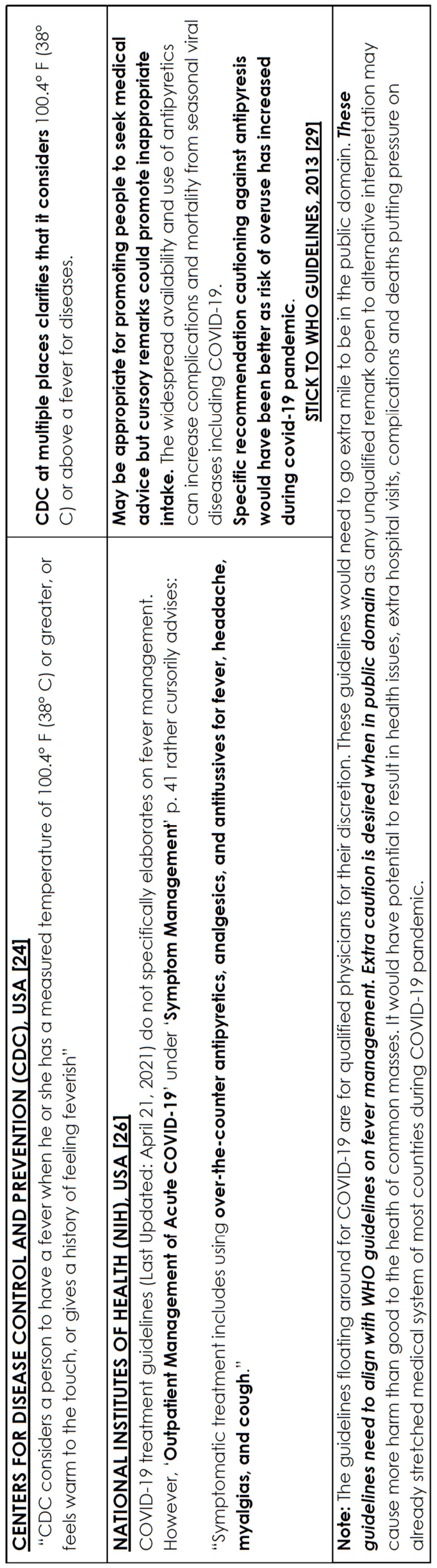

made explicitly for the guidance of general practitioner who clearly understands the meaning of 'uncomfortable' 'fit for treatment' or 'fever that needs treatment' or include their exact meaning/value for common users and state what are the 'signs' or 'dangers' when they may seek emergency medical attention.

\section{CONCLUSION:}

Further blurring of the WHO's fever reduction guidelines reach and their adherence during the pandemic as a result of the appearance of more confusing COVID-19 guidelines from different agencies could negatively impact the health of populations, effectively denying them the benefits of 'harmless fever' or 'pathogen-hyperpyrexia' in eliminating the pathogens. There is a need to align widely accessible guidelines in line with emerging pathogens and therapy options available to us. The temperature upwards of $40{ }^{\circ} \mathrm{C}$ being permissive for certain pathogens, further complicates the situation in the ongoing COVID-19 pandemic. Excessive fever reduction regimens or promotion of such behaviors in masses to not allow the fever to do its job has a more damaging consequence for individuals than imagined for as the restrictive temperature for some strains of Influenzae, Measles and SARS-CoV-2's is around $40^{\circ} \mathrm{C}$. The actual contribution of the unnecessary antipyresis to the increased transmission rate, complications, hospitalization, and deaths from different diseases would only become known in the future through retrospective observational studies. Nevertheless, the existing accumulated evidence and understanding of the beneficial role of fever during infections in the elimination of pathogens without effective therapeutics would favor the timely undertaking of steps by various health agencies to limit the consequences of confusing fever reduction guidelines in public space to effectively alleviate the pressure on overstretched medical infrastructure and possible impact on masses' health and wellbeing during the current COVID-19 pandemic.

Funding: No specific source of funding was utilized for the current study. SS acknowledges the funding support from the Institute of Eminence (loE) seed grant, Banaras Hindu University to his laboratory.

Competing Interest: The author declares no competing interest.

Author contribution: SS - Conceptualization and Writing. RKS and DK - critical inputs, writing and refining the manuscript.

Acknowledgment: The critical insights and inputs provided by Dr. Manish Singh, MD(Pathology), Sanjay Gandhi Post Graduate Institute of Medical Sciences, Lucknow, India on 
the topic, during the development of the theme and writing of manuscript have been crucial in allowing the manuscript to take its current form. His support and contributions are deeply valued and acknowledged.

\section{REFERENCES:}

1. Evans SS, Repasky EA, Fisher DT. Fever and the thermal regulation of immunity: the immune system feels the heat. Nat Rev Immunol. 2015;15(6):335-49. Doi: 10.1038/nri3843.

2. Kluger MJ, Kozak W, Conn CA, Leon LR, Soszynski D. The adaptive value of fever. Infect Dis Clin North Am. 1996 Mar;10(1):1-20. Doi: 10.1016/s08915520(05)70282-8.

3. Plaisance KI, Mackowiak PA. Antipyretic Therapy Physiologic Rationale, Diagnostic Implications, and Clinical Consequences. Intern Med. 2000;160(4):449456. Doi:10.1001/archinte.160.4.449

4. Kluger MJ. The adaptive value of fever. In Fever: basic mechanisms and management (ed. PA Mackowiak), 1991. Pp. 105-124. New York, NY: Raven Press Ltd.

5. Kluger MJ, Ringler DH, Anver MR. Fever and survival. Science. 1975 Apr 11;188(4184):166-8.

6. Hasday JD, Fairchild KD, Shanholtz C. The role of fever in the infected host. Microbes Infect. 2000;2, 1891-1904. Doi:10.1016/S1286-4579(00)01337-X \& Hasday JD, Singh IS. Fever and the heat shock response: distinct, partially overlapping processes. Cell Stress Chaperones. (2000) 5:471-80. doi: 10.1379/1466-1268(2000)005<0471:fathsr>2.0.co;2

7. Blatteis CM. Fever: pathological or physiological, injurious or beneficial? J. Thermal Biol. 2003; 28, 1-13. Doi:10.1016/S0306-4565(02)00034-7

8. Simon HB. Hyperthermia, fever, and fever of undetermined origin. In Infectious diseases: the clinician's guide to diagnosis, treatment, and prevention. (ed. DC Dale). 2003. New York, NY: WebMD Professional Publishing.

9. Carmichael LE, Barnes FD, Percy DH. Temperature as a factor in resistance of young puppies to canine herpesvirus. J Infect Dis. 1969 Dec;120(6):669-78. Doi: 10.1093/infdis/120.6.669.

10. Shann F. Antipyretics in severe sepsis. Lancet. 1995 Feb 11;345(8946):338. Doi: 10.1016/s01406736(95)90337-2

11. Bernheim HA, Kluger MJ. Fever: effect of druginduced antipyresis on survival. Science. $1976 \mathrm{Jul}$ 16;193(4249):237-9. Doi: 10.1126/science.935867

12. Murphy KM. Janeway's immunobiology, $8^{\text {th }}$ edn. 2011. New York, NY: Garland Science.

13. Punt J, Stranford SA, Jones PP, Owen JA. Kuby Immunology. $8^{\text {th }}$ Edn. 2019. New York, NY: W. H. Freeman and Company. ISBN-13 :978-1-319-26722-3

14. Schmitt, B. Fever phobia. Misconceptions of parents about fevers. American Journal of Diseases of Children, 1980; 134(2), 176-181.

15. May A, Bauchner H. Fever phobia: the pediatrician's contribution. Pediatrics. 1992; 90(6):851-4.

16. Blumenthal I. What parents think of fever. Fam Pract. 1998 Dec;15(6):513-8. Doi: 10.1093/fampra/15.6.513.
17. Crocetti M, Moghbeli N, Serwint J. Fever phobia revisited: have parental misconceptions about fever changed in 20 years? Pediatrics. 2001 Jun;107(6):1241-6. Doi: 10.1542/peds.107.6.1241.

18. Demir F, Sekreter $O$. Knowledge, attitudes and misconceptions of primary care physicians regarding fever in children: a cross sectional study. Ital J Pediatr. 2012 Sep 5;38:40. Doi: 10.1186/1824-7288-38-40.

19. Zyoud SH, Al-Jabi SW, Sweileh WM, Nabulsi MM, Tubaila MF, Awang R, Sawalha AF. Beliefs and practices regarding childhood fever among parents: a cross-sectional study from Palestine. BMC Pediatr. 2013 Apr 28;13:66. Doi: 10.1186/1471-2431-13-66.

20. El-Radhi AS. Why is the evidence not affecting the practice of fever management? Arch Dis Child. 2008 Nov;93(11):918-20. doi: 10.1136/adc.2008.139949.. ElRadhi AS. Fever management: Evidence vs current practice. World J Clin Pediatr. 2012;1(4):29-33. Published 2012 Dec 8. doi:10.5409/wjcp.v1.i4.29

21. Silva HD, Silva SD, Weerasekera K. P385 Primary caregivers knowledge on home management of childhood fever. Archives of Disease in Childhood 2019;104:A310-A311.

http://dx.doi.org/10.1136/archdischild-2019-epa.731

22. Concilla A, Kovacik R, Kobilis J, Stobart-Gallagher M. A Survey of Caregivers' Knowledge on Detection and Management of Pediatric Fever. Cureus. 2021 Mar 31;13(3):e14222. Doi: 10.7759/cureus.14222.

23. National Health Service (NHS). Inform. Fever in Adults. Available at https://www.nhsinform.scot/illnessesand-conditions/infections-and-poisoning/fever-inadults (Last updated:08 February 2021; Accessed 5 May 2021)

24. Centers for Disease Control and Prevention (CDC) USA. Definitions of Symptoms for Reportable Illnesses. https://www.cdc.gov/quarantine/air/reportingdeaths-illness/definitions-symptoms-reportableillnesses.html (Last Updated \& Accessed on 14 May 2021)

25. National Health Service (NHS). NHS inform. Illness and Conditions. Infections and poisioning. Coronavirus (COVID-19): General Advice \& Self-care advice. NHS Scotland. Available at https://www.nhsinform.scot/illnesses-andconditions/infections-and-poisoning/coronaviruscovid-19/caring-for-a-cough-or-fever/coronaviruscovid-19-self-care-advice

https://www.nhsinform.scot/illnesses-andconditions/infections-and-poisoning/coronaviruscovid-19/coronavirus-covid-19-general-advice [Last updated and Accessed 14 May 2021]

26. COVID-19 Treatment Guidelines Panel. Coronavirus Disease 2019 (COVID-19) Treatment Guidelines. National Institutes of Health. Available at https://www.covid19treatmentguidelines.nih.gov/. [Accessed May 16, 2021]

27. National Institutes of Health. COVID-19 Treatment Guidelines. Outpatient Management of Acute COVID-19. National Institutes of Health. Available at https://www.covid19treatmentguidelines.nih.gov/out patient-management/ [Last Updated: April 21, 2021]

28. Indian Council of Medical Research (ICMR). FAQs for Patients with Hypertension, Diabetes and Heart 
Diseases in view of Coronavirus/COVID-19 Pandemic. Indian Council of Medical Research, New Delhi, India. Available at https://www.icmr.gov.in/pdf/covid/faqs/FAQs_Englis h_24032020.pdf (Accessed: May 16, 2021)

29. Guidelines Review Committee, World Health Organization. Pocket book of hospital care for children: guidelines for the management of common childhood illnesses - $2^{\text {nd }}$ ed. Geneva: World Health Organization. 2013, ISBN: 978924154837 3. Available at https://www.who.int/publications/i/item/978-92-4154837-3 and http://apps.who.int/iris/bitstream/10665/81 170/1/9789 241548373_eng.pdf [Accessed on 28 April, 2021]

30. National Collaborating Centre for Women's and Children's Health (UK) (2013). NICE guideline: Feverish illness in children - Assessment and initial management in children younger than 5 years, Vol. C160 London: National Institute for Health and Care Excellence.

31. Indian Council of Medical Research (ICMR). 'Management of Acute Fever' in 'Treatment Guidelines for Antimicrobial Use in Common Syndromes'. 2nd edition. Indian Council of Medical Research, Department of Health Research, New Delhi, India. 2019, P:10 https://main.icmr.nic.in/sites/default/files/guidelines/T reatment_Guidelines_2019_Final.pdf

32. NSW Health, (2010). Infants and children: acute management of fever / NSW Health. North Sydney, N.S.W: NSW Dept. of Health.

33. SA Health. (2013). Management of Fever without Focus in Children (excluding neonates) Clinical Guideline. S.A.: Government of South Australia

34. Simpson WM. Artificial Fever Therapy of Syphilis and Gonococcic Infections. $\mathrm{Br} \mathrm{J}$ Vener Dis. 1936 Jul;12(3):133-66. Doi: 10.1136/sti.12.3.133.

35. Chadwick J, Mann WN. The medical works of Hippocrates. Oxford: Blackwell, 1950: 204.

36. Young PJ, Saxena MK, Beasley RW. Fever and antipyresis in infection. Med J Aust. 2011 Oct 17;195(8):458-9. Doi: 10.5694/mja1 1.10502.

37. Solomon HC, Kopp I. Fever therapy. N Engl J Med 1937; 217: 805-814 DOl: 10.1056/NEJM193711182172101

38. Mackowiak PA. Direct effects of hyperthermia on pathogenic microorganisms: Teleologic implications with regard to fever. Rev Infect Dis. 1981 MayJun;3(3):508-20. Doi: 10.1093/clinids/3.3.508.

39. Mackowiak PA, Marling-Cason M, Cohen RL. Effects of temperature on antimicrobial susceptibility of bacteria. J Infect Dis. 1982 Apr;145(4):550-3. Doi: 10.1093/infdis/145.4.550.

40. Lwoff A. From protozoa to bacteria and viruses. Fifty years with microbes (André Lwoff). Annu Rev Microbiol. 1971;25:1-26. doi: 10.1146/annurev.mi.25.100171.000245.

41. Osawa E, Muschel, L H. Studies relating to the serum resistance of certain Gram-negative bacteria. J Exp Med. 1964 Jan 1;119(1):41-51. doi: 10.1084/jem.119.1.41

42. Pockley AG, Calderwood SK, Santoro MG. Prokaryotic and Eukaryotic Heat Shock Proteins in Infectious Disease Springer Netherlands, 2010. DOI: 10.1007/978-90-481-2976-8. ISBN: 978-90-481-2976-8
43. Akerfelt $M$, Morimoto RI, Sistonen L. Heat shock factors: integrators of cell stress, development and lifespan. Nat Rev Mol Cell Biol. 2010 Aug; 11 (8):545-55. doi: 10.1038/nrm2938.

44. Hasday JD, Thompson C, Singh IS. Fever, immunity, and molecular adaptations. Compr Physiol. 2014 Jan;4(1):109-48. doi: 10.1002/cphy.c130019..

45. Taipale $M$, Jarosz DF, Lindquist S. HSP90 at the hub of protein homeostasis: emerging mechanistic insights. Nat Rev Mol Cell Biol. 2010 Jul;11(7):515-28. doi: 10.1038/nrm2918.

46. LeGrand EK, Alcock J. Turning up the heat: immune brinksmanship in the acute-phase response. Q Rev Biol. 2012 Mar;87(1):3-18. Doi: 10.1086/663946.

47. Schneider WM, Chevillotte MD, Rice CM. Interferonstimulated genes: a complex web of host defenses. Annu Rev Immunol. 2014;32:513-45. doi: 10.1146/annurev-immunol-032713-120231.

48. Roberts NJ Jr. Impact of temperature elevation on immunologic defenses. Rev Infect Dis. 1991 MayJun;13(3):462-72. Doi: 10.1093/clinids/13.3.462

49. Russell FM, Shann F, Curtis N, Mulholland K. Policy and Practice: Evidence on the use of paracetamol in febrile children. Bulletin of the World Health Organization 2003, 81 (5): 367-374 World Health Organization.

[https://apps.who.int/iris/bitstream/handle/10665/719 85/bulletin_2003_81\%285\%29_367-

372.pdf? sequence $=1$ \&isAllowed=y (Last Accessed 20 May, 2021)]

50. Yan N, Chen Z. Intrinsic antiviral immunity. Nat Immunol. 2012; 13: 214-222. https://doi.org/10.1038/ni.2229

51. Mourtzoukou EG, Falagas ME. Exposure to cold and respiratory tract infections. Int J Tuberc Lung Dis. 2007 Sep; 11 (9):938-43.

52. Anckar J, Sistonen L. Regulation of HSFl Function in the Heat Stress Response: Implications in Aging and Disease. Annu. Rev. Biochem. 2011. 80:1089-115. doi:10.1146/annurev-biochem-060809-095203

53. Takii $R$, Inouye $S$, Fujimoto $M$, Nakamura $T$, Shinkawa $T$, Prakasam R, Tan K, Hayashida N, Ichikawa H, Hai T, Nakai A. Heat shock transcription factor 1 inhibits expression of $\mathrm{IL}-6$ through activating transcription factor 3. J Immunol. 2010 Jan 15;184(2):1041-8. doi: 10.4049/jimmunol.0902579

54. Xiao X, Zuo X, Davis AA, McMillan DR, Curry BB, Richardson JA, Benjamin IJ. HSFI is required for extraembryonic development, postnatal growth and protection during inflammatory responses in mice. EMBO J. 1999 Nov 1;18(21):5943-52. doi: 10.1093/emboj/18.21.5943

55. Heck TG, Ludwig MS, Frizzo MN, Rasia-Filho AA, Homem de Bittencourt PI. Suppressed antiinflammatory heat shock response in high-risk COVID19 patients: lessons from basic research (inclusive bats), light on conceivable therapies. Clin Sci (Lond). 2020 Aug 14;134(15):1991-2017. doi: 10.1042/CS20200596.

56. Martins M, Abecasis F. Healthcare professionals approach paediatric fever in significantly different ways and fever phobia is not just limited to parents. 
Acta Paediatr. 2016 Jul;105(7):829-33. doi: 10.1111 /apa.13406.

57. Schmitt BD. Fever phobia: misconceptions of parents about fevers. Am J Dis Child. 1980 Feb;134(2):176-81.

58. Seattle Children's Hospital. Fever - Myths Versus Facts. Seattle,

WA

https://www.seattlechildrens.org/conditions/a-

z/fever-myths-versus-facts/

(Accessed on 13 May 2021; Last Reviewed:

05/13/2021; Last Revised: 03/11/2021)

59. Thomas V, Riegel B, Andrea J, Murray P, Gerhart A, Gocka I. National survey of pediatric fever management practices among emergency department nurses. J Emerg Nurs. 1994 Dec;20(6):50510.

60. Kiekkas P, Konstantinou E, Psychogiou KS, Tsampoula I, Stefanopoulos N, Bakalis N. Nursing personnel's attitudes towards fever and antipyresis of adult patients: cross-sectional survey. J Clin Nurs. 2014 Oct;23(19-20):2949-57. doi: 10.1111/jocn.12551.

61. Ellis FR. Malignant hyperpyrexia. Archives of Disease in Childhood, 1984; 59: $1013-1015$

https://adc.bmj.com/content/archdischild/59/1 1/ 1013.full.pdf

62. Mclntyre J. Management of fever in children. Archives of Disease in Childhood, 2011:96(12):11731174 . http://dx.doi.org/10.1136/archdischild-2011301094

63. Section on Clinical Pharmacology and Therapeutics; Committee on Drugs, Sullivan JE, Farrar HC. Fever and antipyretic use in children. Pediatrics. 2011 Mar;127(3):580-7. doi: 10.1542/peds.2010-3852.

64. Ekholm E, Niemineva K. On convulsions in early childhood and their prognosis; an investigation with follow-up examinations of patients treated for convulsions at the Children's Clinic of Helsinki University. Acta Paediatr. 1950;39(6):481-501. doi: 10.1111/j.1651-2227.1950.tb08545.x.

65. Earn DJ, Andrews PW, Bolker BM. Population-level effects of suppressing fever. Proc Biol Sci. 2014 Jan 22;281 (1778):20132570. doi: 10.1098/rspb.2013.2570.

66. Dinarello CA, Porat R. 2019. In Harrison's principles of internal medicine leds AS Fauci, DL Kasper, DL Longo, E Braunwald, SL Hauser, JL Jameson, J Loscalzo), 20th edn, New York, NY: McGraw-Hill.

67. Schell-Chaple HM, Puntillo KA, Matthay MA, Liu KD, Wiedemann HP, Arroliga AC, et al. Body temperature and mortality in patients with acute respiratory distress syndrome. Am J Crit Care. (2015) 24:15-23. doi: $10.4037 /$ ajcc2015320

68. Schulman $\mathrm{Cl}$, Namias $\mathrm{N}$, Doherty J, Manning RJ, Li P, Alhaddad A, et al. The effect of antipyretic therapy upon outcomes in critically ill patients: a randomized, prospective study. Surg Infect. 2005;6:369-75. doi: 10.1089/sur.2005.6.369

69. Petitjeans F, Leroy S, Pichot C, Geloen A, GhignoneM, Quintin L. Hypothesis: fever control, a niche for alpha2 agonists in the setting of septic shock and severe acute respiratory distress syndrome? Temperature. 2018; 5:224-56. doi: 10.1080/23328940.2018.1453771

70. Inouye S, IzU H, Takaki E, Suzuki H, Shirai M, Yokota Y, Ichikawa $H$, Fujimoto $M$, Nakai A. Impaired IgG production in mice deficient for heat shock transcription factor 1. J Biol Chem. 2004 Sep 10;279(37):38701-9. doi: 10.1074/jbc.M405986200.
71. Murshid A, Eguchi T, Calderwood SK. Stress proteins in aging and life span. Int J Hyperthermia. 2013 Aug;29(5):442-7. doi: 10.3109/02656736.2013.798873.

72. Hooper PL, Hooper JJ., Loss of defense against stress: diabetes and heat shock proteins. Diabetes Technol. Ther. 2005 Feb;7(1):204-8. doi: 10.1089/dia.2005.7.204.

73. Kurucz I, Morva A, Vaag A, Eriksson KF, Huang X, Groop L, Koranyi L. Decreased expression of heat shock protein 72 in skeletal muscle of patients with type 2 diabetes correlates with insulin resistance. Diabetes. $2002 \quad$ Apr;51(4):1102-9. doi: 10.2337/diabetes.51.4.1102..

74. Weiss YG, Bouwman A, Gehan B, Schears G, Raj N, Deutschman CS. Cecal ligation and double puncture impairs heat shock protein 70 (HSP-70) expression in the lungs of rats. Shock. 2000 Jan;13(1):19-23. doi: 10.1097/00024382-20001301000004.

75. Schroeder S, Lindemann C, Hoeft A, Putensen C, Decker D, von Ruecker AA, Stüber F. Impaired inducibility of heat shock protein 70 in peripheral blood lymphocytes of patients with severe sepsis. Crit Care Med. 1999 Jun;27(6):1080-4. doi: 10.1097/00003246-199906000-00023.

76. Duan X, Berthiaume F, Yarmush D, Yarmush ML. Proteomic analysis of altered protein expression in skeletal muscle of rats in a hypermetabolic state induced by burn sepsis. Biochem J. 2006 Jul 1;397(1):149-58. doi: 10.1042/BJ20051710.

77. Marzec L, Zdrojewski Z, Liberek T, Bryl E, Chmielewski M, Witkowski JM, Rutkowski B. Expression of Hsp72 protein in chronic kidney disease patients. Scand J Urol Nephrol. 2009;43(5):400-8. doi: 10.3109/00365590903089489.

78. Cappello F, Di Stefano A, David S, Rappa F, Anzalone R, La Rocca G, D'Anna SE, Magno F, Donner CF, Balbi B, Zummo G. Hsp60 and Hspl0 down-regulation predicts bronchial epithelial carcinogenesis in smokers with chronic obstructive pulmonary disease. Cancer. 2006 Nov 15;107(10):2417-24. doi: 10.1002/cncr.22265.

79. Xie J, Zhao J, Xiao C, XU Y, Yang S, Ni W. Reduced heat shock protein 70 in airway smooth muscle in patients with chronic obstructive pulmonary disease. Exp Lung Res. 2010 May;36(4):219-26. doi: $10.3109 / 01902140903349562$.

80. Stanley ED, Jackson GG, Panusarn C, Rubenis $M$, Dirda $V$. Increased virus shedding with aspirin treatment of rhinovirus infection. JAMA. 1975 Mar 24;231 (12):1248-51.

81. Doran TF, De Angelis C, Baumgardner RA, Mellits ED. Acetaminophen: more harm than good for chickenpox? J Pediatr. 1989 Jun;114(6):1045-8. doi: 10.1016/s0022-3476(89)80461-5..

82. Jefferies S, Weatherall M, Young P, Eyers S, Beasley R. Systematic review and meta-analysis of the effects of antipyretic medications on mortality in Streptococcus pneumoniae infections. Postgrad Med J. 2012 Jan;88(1035):21-7. doi: 10.1136/postgradmedj-2011130217.

83. Ahkee S, Srinath L, Ramirez J. Community-acquired pneumonia in the elderly: association of mortality with lack of fever and leukocytosis. South Med J. 1997 Mar;90(3):296-8. doi: 10.1097/00007611199703000-00006. 
84. Kuikka A, Sivonen A, Emelianova A, Valtonen VV. Prognostic factors associated with improved outcome of Escherichia coli bacteremia in a Finnish university hospital. Eur J Clin Microbiol Infect Dis. 1997 Feb;16(2):125-34. doi: 10.1007/BF01709471.

85. Kuikka A, Valtonen VV. Factors associated with improved outcome of Pseudomonas aeruginosa bacteremia in a Finnish university hospital. Eur J Clin Microbiol Infect Dis. 1998 Oct;17(10):701-8. doi: $10.1007 /$ s100960050164

86. Eyers S, Weatherall M, Shirtcliffe P, Perrin K, Beasley R. The effect on mortality of antipyretics in the treatment of influenza infection: systematic review and meta-analysis. J R Soc Med. 2010;103(10):40341 1. doi:10.1258/jrsm.2010.090441

87. Güllüoğlu BM, Aksoy BS, Ozveri ES, Yüksel M, Demiralp $\mathrm{EE}$, Aktan AO. Optimal timing and temperature for hyperthermic preconditioning in an animal model of fecal peritonitis. J Invest Surg. 2002 MayJun;15(3):1 17-24. doi: 10.1080/08941930290085877.

88. $\mathrm{X} \cup \mathrm{H}$, Aibiki M, Nagoya J. Neuroprotective effects of hyperthermic preconditioning on infarcted volume after middle cerebral artery occlusion in rats: role of adenosine receptors. Crit Care Med. 2002 May;30(5):1 126-30. doi: 10.1097/00003246-20020500000028.

89. Yamashita N, Hoshida S, Taniguchi N, Kuzuya T, Hori M. Whole-body hyperthermia provides biphasic cardioprotection against ischemia/reperfusion injury in the rat. Circulation. 1998 Oct 6;98(14):1414-21. doi: 10.1161/01.cir.98.14.1414.

90. Oba M, Suico MA, Morino S, Yano S, Matsuno T, Koga T, Sato T, Shuto T, Kai H. Modified mild heat shock modality attenuates hepatic ischemia/reperfusion injury. J Surg Res. 2010 Aug;162(2):213-20. doi: 10.1016/j.jss.2009.03.093.

91. El-Radhi AS. Fever management: Evidence vs current practice. World J Clin Pediatr. 2012;1(4):29-33. Published 2012 Dec 8. doi:10.5409/wjcp.v1.i4.29

92. World Health Organization. Integrated Management of Childhood Illness. Geneva: World Health Organization; 2000. WHO document WHO/FCH/CAH/00.12.

93. Heubi JE, Barbacci MB, Zimmerman HJ. Therapeutic misadventures with acetaminophen: hepatoxicity after multiple doses in children. J Pediatr. 1998 Jan;132(1):22-7. doi: 10.1016/s0022-3476(98)70479-2.

94. Kearns GL, Leeder JS, Wasserman GS. Acetaminophen overdose with therapeutic intent. J Pediatr. 1998 Jan;132(1):5-8. doi: 10.1016/s00223476(98)70476-7.

95. Rivera-Penera T, Gugig R, Davis J, McDiarmid S, Vargas J, Rosenthal P, Berquist W, Heyman MB, Ament ME. Outcome of acetaminophen overdose in pediatric patients and factors contributing to hepatotoxicity. J Pediatr. 1997 Feb;130(2):300-4. doi: 10.1016/s0022-3476(97)70359-7.

96. Penna AC, Dawson KP, Penna CM. Is prescribing paracetamol 'pro re nata' acceptable? J Paediatr Child Health. 1993 Apr;29(2):104-6.6. 